\section{Photoanthropometry of the Face in the Young White Brazilian Population}

\author{
Paola Sampaio Gonzales ${ }^{1}$, Carlos Eduardo Palhares Machado², Edgard \\ Michel-Crosato ${ }^{1}$
}

${ }^{1}$ Community Dentistry Department, School of Dentistry, USP- Universidade de São Paulo, São Paulo, SP, Brazil

${ }^{2}$ National Institute of Criminalistics, Brazilian Federal Police, Ministry of Justice, Brasília, DF, Brazil

Correspondence: Paola Sampaio Gonzales, Av Professor Lineu Prestes, 2227, 05508-000 São Paulo, SP, Brasil. Tel: 55-11-3091-7891.

e-mail: paola.gonzales@usp.br
The aim of the present study is to describe the simplified facial pattern of young Brazilian men and women using the facial index (FI), upper face index (UFI), and nasal index (NI) in indirect anthropometric measurements applied to frontal photographic images. The images were obtained from 660 adult white men and 689 adult white women aged 30 years \pm 6 months, and classified according to regions of birth, as follows: south (S), southeast (SE), midwest (MW), northeast (NE), and north (N). The nasion, zygion, gnathion, stomion, subnasale, and alare landmarks were labeled on the images using the SAFF $2 D^{\circledast}$ software. Based on the coordinates, the linear distances between the landmarks of interest were calculated and presented as indices. The analysis of variance and Student's t-test were used for assessing the regions of birth and gender, respectively. The collected data allowed obtaining the facial profile of the young adult Brazilian population. There were differences in the facial profiles between men and women and also between some regions, especially between the $\mathrm{N}$ and the other Brazilian regions $(p<0.05)$. The UFI did not show a statistically significant difference $(p>0.05)$ between genders for any of the regions. The discriminant analysis for gender assessment demonstrated higher accuracy when the three indices were analyzed together. In the decision tree for gender assessment, the NI showed better results than the other indices.
Key Words: anthropometry, face, nose, sex characteristics.

\section{Introduction}

Anthropometry is widely used in areas such as medicine, dentistry, nutrition, and arts. This technique is of utmost importance in facial analysis, as it helps diagnose craniofacial anomalies (1), set a standard for the planning of facial reconstruction surgeries (2), and establish growth and aging patterns $(3,4)$.

While facial analysis is employed in numerous fields of modern science, the single reference standard, which dates back to the Renaissance period, does not correspond to the current ideals of facial harmony. Populations change over time and a single pattern cannot represent all peoples and ancestries, which have notable differences in their physical features (5). Facial anthropometric parameters have been described for the Caucasian population for 30 years (6). However, several authors have proven there are differences across population groups and have thus underscored the importance of investigating several populations. Despite the importance of such data, information on the Brazilian population is still lacking, probably because larger and more representative samples of the whole country are required.

Anthropometric measurements are either direct (applied directly to the subject) or indirect (based on the representation of an individual, including, for instance, photographs and computerized tomography images). Photography is an acceptable method for the measurement of facial parameters and it is used by many authors (7-9).

The aim of this study is to verify the facial patterns of male and female young adult Brazilians by assessing the facial index (FI), upper face index (UFI), and nasal index (NI) and the differences between them as well as peculiar characteristics of each Brazilian region. Discriminant and tree decision analyses were utilized for gender assessment. The null hypothesis is that there are no differences in facial indices between genders and the Brazilian regions.

\section{Material and Methods}

All the principles of the Declaration of Helsinki were followed. The study was approved by the local Research Ethics Committee (Process no. 1484305).

Indirect anthropometric measurements were made based on frontal facial photographs of 660 men and 689 women obtained from the Brazilian Federal Police database. The identities of the subjects were kept confidential pursuant to the security standards followed by Brazilian Federal Police civil servants.

The following criteria were adopted in the present study: a test power of 0.80 ; a significance level of 0.05 ; a standard error of $2 \%$; and the inclusion of $10 \%$ more images to make up for occasional losses. At least 120 images of white young adults aged 30 years ( \pm 6 months) were included for each Brazilian region, namely: south (S), southeast (SE), midwest $(\mathrm{MW})$, northeast (NE), and north (N).

The images were included following these criteria: images made with a $35 \mathrm{~mm}$ equivalent focal length using a digital camera positioned at the eye level of the subject 
being photographed, at a distance of approximately 1.5 meters; images with a resolution equal to or greater than $480 \times 640$ pixels and 24-bit RGB; images with the face positioned centrally on the sagittal plane and sagittal axis; individuals with a neutral facial expression, with their lips closed, looking straight into the camera; absence of global features such as beard, mustache, makeup or accessories that could hinder the visualization of facial structures of interest; absence of severe asymmetries, evident deformations, or plastic surgeries that could bias the outcomes. Images on which the face was not centrally positioned were excluded, and so were those on which subjects were smiling, had strabismus, or were not looking straight into the camera, or if the self-reported gender did not match the one seen on the image.

Proper images were classified as to ancestry, keeping only those that shared common characteristics and depicted white individuals. The inclusion criteria were: beige or pink skin color (fair skin), thin or medium-sized lips, and narrow or medium-sized nasal base. The exclusion criteria were: naturally ulotrichous hair (curly hair), large nasal base compatible with that seen in black individuals, thick lips compatible with those of black individuals, and agreed with either of the other two researchers, the image was included in the sample; otherwise, it was excluded.

Nasion (n), zygion (zy), gnathion (gn), stomion (sto), subnasale (sn), and alare (al) landmarks were manually

recorded by the researchers, using the SAFF $2 \mathrm{D}^{\circledR}$ - the $2 \mathrm{D}$ forensic facial analysis software program developed by the Brazilian Federal Police (Fig. 1).

Intrarater and interrater agreement analyses were performed using the intraclass correlation coefficient. For the analysis of intrarater reliability, 10 duplicate images, at an interval greater than 15 days, were marked by the same researcher.

The two-dimensional coordinates of the assessed points were stored on Federal Police web servers and exported to Microsoft EXCEL ${ }^{\circledR}$. For the statistical analysis, the coordinates, recorded in pixels, were changed into linear distances calculated by the geometric formula for the distance between two points, according to equation .

The n-gn, zy-zy, n-sto, al-al, and n-sn linear distances were changed into indices, as follows: $\mathrm{Fl}=\mathrm{n}$-gn.100/zy-zy, $\mathrm{UFI}=\mathrm{n}$-sto.100/zy-zy, and $\mathrm{Nl}=\mathrm{al}-\mathrm{al} .100 / \mathrm{n}-\mathrm{sn}$ (Fig. 1).

The descriptive and statistical analyses were performed with the Mini Tab 17 and Stata 14.3 software programs. Student's t test was used to assess the difference between the means obtained for men and women. The analysis of variance, with Bonferroni post-hoc test, was used to estimate the difference across Brazilian regions (10). The significance level was set at $95 \%(p=0.05)$ for all tests.

Data mining was employed for gender assessment, using the Orange 3.4.2 software.

\section{Results}

A total of 1,349 frontal photographs of 660 Brazilian men and 689 Brazilian women aged 30 years ( \pm 6 months), sorted by region of birth, were assessed. The correlation coefficient revealed intrarater and interrater reliability.
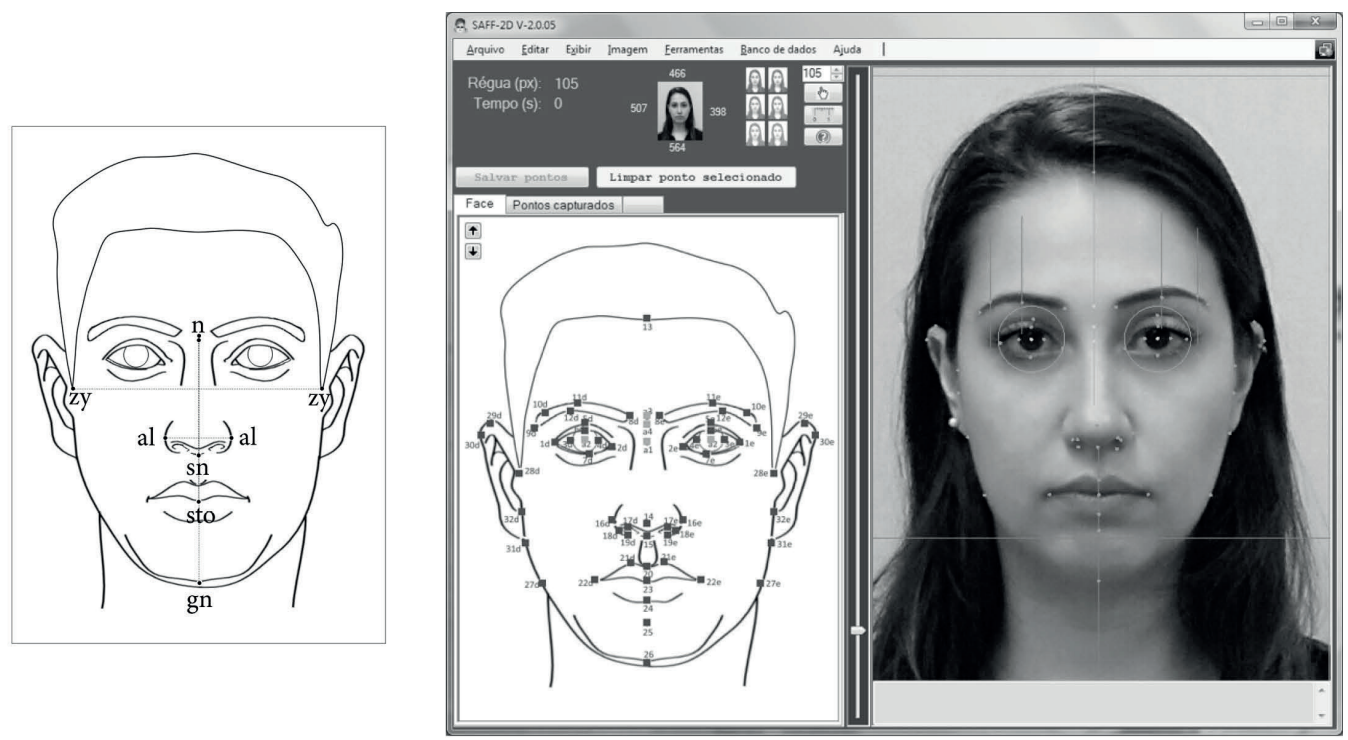

Figure 1. Location of points and distances that make up FI, UFI, and NI, respectively, and the layout of the SAFF 2D ${ }^{\circledR}$ software. On the left: template with the points available for marking, and on the right: photographic image to be manually marked by the examiners. 
Analyzing the Brazilian population as a whole, there was a statistically significant difference between genders for the three indices $(p>0.05)$. UFI did not show a significant difference $(p>0.05)$ between genders for any of the regions.

By taking only female individuals into account, $\mathrm{FI}$ revealed some differences between the $\mathrm{N}$ region and all the other regions. UFI showed some differences $(p<0.05)$ between the $\mathrm{N}$ region and the $\mathrm{S}, \mathrm{SE}$, and $\mathrm{MW}$ regions. $\mathrm{NI}$ also indicated some differences $(p<0.05)$ between the $\mathrm{N}$ region and the other regions, in addition to differences between the NE region and the $\mathrm{S}$ and SE regions. Regarding male individuals, the analysis indicated variation in $\mathrm{FI}$ and UFI $(p<0.05)$ for the $S$ and NE regions, and also between the $N$ region and the $S, S E$, and $M W$ regions. UFI also differed $(p<0.05)$ between the NE and N regions. NI showed some differences $(p<0.05)$ across regions: between the $S$ region and the $S E, N E$, and $N$ regions, and between the $M W$ region

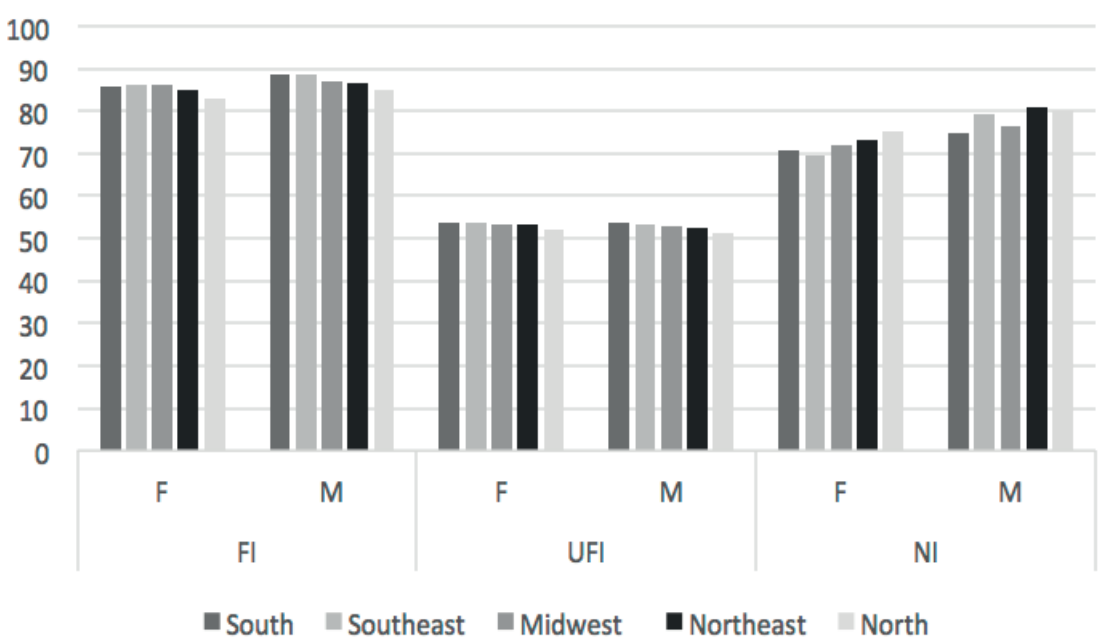

Figure 2. Graph showing the difference between the means obtained for facial index (FI), upper face index (UFI) and nasal index (NI) for men and women by region of birth.

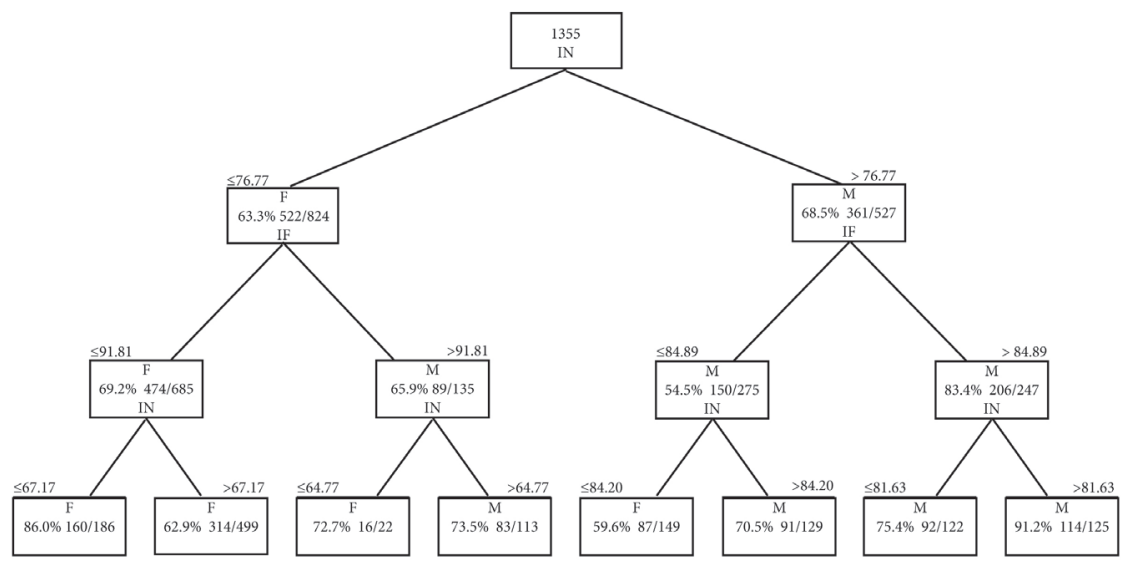

Figure 3. Decision tree for gender assessment, Brazil 2017. and the $\mathrm{N}$ and NE regions.

The indices per region of birth and gender are graphically represented in Figure 2.

The discriminant analysis for gender assessment demonstrated better accuracy rates (70\% for men and $73 \%$ for women) when the three indices were analyzed together. The equation for males was $\mathrm{S}=-371.24+\left(\mathrm{F}{ }^{*} 0.73\right)$ $+\left(\mathrm{UFI}^{*} 7.70\right)+\left(\mathrm{UFI}^{*} 3.49\right)$ and the one for females was $\mathrm{S}=-$ $353.03+\left(\mathrm{Fl}^{*} 0.50\right)+\left(\mathrm{UFI}^{*} 7.87\right)+\left(\mathrm{UFl} \mathrm{l}^{*} 3.39\right)$.

In addition, data mining with machine learning shown in the decision tree was used for gender assessment (Fig. 3). $\mathrm{NI}$ had the best results for gender (gain ratio $=0.04$ and Gini coefficient $=0.05$ ), with a $76.77 \%$ cutoff point.

\section{Discussion}

Indirect anthropometric measurements based on standardized photographs have the following advantages: the object being measured does not move; errors caused by pressure of the instrument on the skin are avoided; landmarks can be made several times without causing any disturbance to the subject being measured; and the information can be stored for future access (11). However, the indirect method shows some variability when absolute values are assessed at some points, when compared with the direct manual method. This variability has to do with the researcher's difficulty in finding the points on the image, due to the loss of some anatomic references, to distortions on the photographs, to differences in object's plane structures and in the image represented on the photograph, or to distortion of soft tissues in direct landmarks caused by pressure of the instrument, which could lead to errors $(7,12)$. However, there is some agreement between direct and indirect anthropometric measurements regarding some points which, combined with the advantages of the method, substantiates its use $(1,7,9,11)$. Moreover, the use of proportions for the analysis of the results minimizes possible distortions of 
the image from the real object, since the magnification factor is eliminated (13).

The present study focused on white individuals, as this population accounts for $47.7 \%$ of Brazilians, as pointed out by the 2010 census carried out by the Brazilian Institute of Geography and Statistics. The criteria for classification of complexion, nose morphology, and lip thickness are described in the literature as predictors of ancestry/ ethnicity (14).

The age of 30 years ( \pm 6 months) at the time of the photographic record was chosen because it represents soft tissue stability, with no interference from growth and aging (15).

Most female individuals can be classified as leptoprosopic $(36.8 \%)$ whereas male individuals are mesoprosopic $(29.74 \%)$ when the overall Fl mean is estimated (5). The difference in $\mathrm{Fl}$ between men and women is also evident in other populations, and this index is usually lower in women than in men $(2,16,17)$.

The upper face corresponds to the distance from the nasal root (n) to the end of the upper lip (sto). To calculate this index, the height is divided by face width (zy). According to UFI, most of the investigated population is classified as $\overrightarrow{5}$ mesen (47.7\%). The UFI mean for the population of this study was 53.2 for females and 52.6 for males. Another study using 3D images of 10 white Brazilians shows a mean of 52.0, which is similar to our findings (18).

$\mathrm{NI}$ shows the relationship between nose width and height. Nose morphology can be associated with the geographic origin of the population, with predominance of mesorrhine individuals in Latin America (19). The difference in nose size between men and women is also observed in other populations $(8,20,21)$.

When the female gender was investigated by region, the S and SE, S and MW, SE and MW, SE and NE, and MW and NE regions did not reveal any differences for any of the three indices. UFI was the index with less remarkable difference across regions, with some difference only between $\mathrm{N}$ and $\mathrm{S}$ and between NE and MW. NI was the index with the most frequent differences between genders, observed between $\mathrm{S}$ and $\mathrm{NE}$ and $\mathrm{N}, \mathrm{SE}$ and $\mathrm{N}$ and $\mathrm{S}$, and $\mathrm{SE}, \mathrm{MW}$ and $\mathrm{N}$.

UFI was the index with the largest variation among men and with the smallest variation among women. Both for men and women, the three indices showed differences between $\mathrm{S}$ and $\mathrm{MW}$ and between SE and MW, but no difference between MW and N.

Considering the territorial distribution of the population, lower means was observed for Fl and UFI for the $\mathrm{N}$ region. UFI did not show statistical differences between males and females for any of the regions. NI showed the highest mean for females. The mean $\mathrm{NI}$ for males was similar for $\mathrm{N}$ and $\mathrm{NE}$.
The differences in facial pattern across regions can be explained by several immigration episodes that took place in Brazil, and also by the country's vast territorial extension. Brazil is a continental country that went through an important migration process, with migrants coming from different European and African countries during its colonization. For over 350 years (1500-1850), Brazil received about 500,000 Portuguese and 4 million African individuals - the latter were concentrated especially in the south and northeast regions. The south was home mainly to immigrants from Italy, Spain, and Germany (22). This distribution is also observed in genetic markers of ancestry, which indicate the larger presence of Europeans in the southern region. African ancestry is widely present in Brazil, except for the southern region, with the highest frequency in the east region. Genetic markers of native Brazilians are predominantly found in the northern region (23). Therefore, interracial marriage is considered to have been a complex process, with noticeable impact on the facial profile of the Brazilian population and, for that reason, the population was assessed by region of birth, in an attempt to describe the facial pattern peculiarities of each region.

A similar study was conducted in Turkey, where the population was analyzed after being split into seven regions with different climate characteristics. Facial measurements turned out to be different across the assessed regions (24).

In the medical area, it is necessary to perform studies on gender characteristics, showing differences between bone and soft tissue measurements in men and women. Gender assessment obtained for the population in the present study showed an accuracy of 70\% for men and $73 \%$ for women. Skull measurements had $77 \%$ to $88 \%$ of accuracy (25), whereas soft tissue measurements reached 94\% (26).

In addition, data mining and machine learning techniques demonstrated that the nasal index is the one that best describes sex differences. The use of algorithms for the analysis of data is a tendency in the healthcare sector and could improve diagnostic accuracy, in addition to allowing for important predictions $(27,28)$.

Even though there is predominance of white individuals in Brazil, relatively dark-skinned, black and native Brazilian individuals have racial representativeness, and further studies should be undertaken to investigate the anthropometric differences between these ancestries.

The data herein allowed obtaining the simple profile of young adult Brazilians. There were differences in the facial profile between genders and also in some regions, especially between the north and the other Brazilian regions. Thus, the null hypothesis was rejected. When sorted by region, UFI did not differ between genders for any of the regions. The discriminant analysis for gender assessment showed better accuracy when the three indices were analyzed 
together. In the decision tree for gender assessment, NI yielded the best results.

As a limitation of this study, authors point out the analysis of white ancestry only, whereas the Brazilian population is made up of white, brown, and black individuals.

\section{Resumo}

0 objetivo do estudo é verificar o padrão facial simplificado a partir dos indices facial (IF), da face superior (IFS) e nasal (IN) de homens e mulheres jovens brasileiros a partir da antropometria indireta aplicada em imagens fotográficas em norma frontal. Foram utilizadas imagens de adultos brancos de 30 anos ( \pm 6 meses), sendo 689 do gênero feminino e 660 do masculino, divididos pela região de nascimento, sendo Sul, Sudeste, Centro-oeste, Nordeste e Norte. Os pontos: násio, zígio, gnátio, estômio, subnasal e alar foram marcados nas imagens por meio do software SAFF $2 \mathrm{D}^{\oplus}$. A partir das coordenadas geradas em pixels, foram calculadas as distâncias lineares entre os pontos de interesse, que foram transformadas em indices. Os indices foram analisados estatisticamente de acordo com a região do nascimento pela análise de variância e o gênero pelo teste $t$ de Student. Com os dados foi possivel traçar o perfil simplificado da face da população brasileira de adultos jovens por meio da fotoantropometria. Foram observadas diferenças no perfil facial entre os gêneros e também entre algumas regiões, com maior frequência entre a região $\mathrm{N}$ e as demais partes do pais $(p<0,05)$. Quando separados por regiões do país, o IFS não mostrou diferença estatisticamente significante $(p>0,05)$ entre os gêneros para nenhuma região. A análise discriminante para estimativa de gênero mostra que melhores taxas de acerto são alcançadas quando considerados os três índices em conjunto. Para a árvore de decisão de estimativa de gênero, o IN desempenhou os melhores resultados, quando comparado aos demais indices analisados.

\section{Acknowledgements}

The authors would like to thank CAPES for financial support (Public Notice no. 25/2014, project 37, PRÓ-FORENSES) and the Technical and Forensic Police for technical support.

\section{References}

1. Guyot L, Dubuc M, Richard O, Philip N, Dutour O. Comparison between direct clinical and digital photogrammetric measurements in patients with 22q11 microdeletion. Int J Oral Maxillofac Surg 2003;32:246-252.

2. Ngeow W, Aljunid S. Craniofacial anthropometric norms of Malaysian Indians. Indian J Dent Res 2009;20:313-319.

3. Farkas LG, Eiben OG, Sivkov S, Tompson B, Katic MJ, Forrest CR. Anthropometric measurements of the facial framework in adulthood: age-related changes in eight age categories in 600 healthy white North Americans of European ancestry from 16 to 90 years of age. J Craniofac Surg 2004;15:288-298

4. Machado CEP, Flores MRP, Lima LNC, Tinoco RLR, Franco A, Bezerra $A C B$, et al. $A$ new approach for the analysis of facial growth and age estimation: Iris ratio. PLoS ONE 12:e0180330.

5. Berneburg M, Dietz K, Niederle C, Göz G. Changes in esthetic standards since 1940. Am J Orthod Dentofacial Orthop 2010;137:450e1-450e9.

6. Farkas LG, Munro IR. Anthropometric facial proportions in medicine. Illinois: Charles C. Thomas Publisher; 1987.

7. Farkas LG, Bryson W, Klotz J. Is Photogrammetry of the Face Reliable?
Plast Reconstr Surg 1980;66:346-355.

8. Ali MHM. External nasal parameters in Egyptians: an in-depth nasal photogrammatic analysis. Surg Radiol Anat 2014;36:633-641.

9. Aksu M, Kaya D, Kocadereli I. Reliability of reference distances used in photogrammetry. Angle Orthod 2010;80:670-677.

10. Ambrosano GMB, Reis AF, Giannini M, Pereira AC. Use of statistical procedures in Brazilian and international dental journals. Braz Dent $J$ 2004;15:231-237.

11. Han K, Kwon HJ, Choi TH, Kim JH, Son D. Comparison of anthropometry with photogrammetry based on a standardized clinical photographic technique using a cephalostat and chair. J Craniomaxillofac Surg 2010;38:96-107.

12. Ghoddousi $H_{1}$ Edler $R$, Haers $P$, Wertheim D, Greenhill D. Comparison of three methods of facial measurement. Int J Oral Maxillofac Surg 2007;36:250-258.

13. Kohout MP, Aljaro LM, Farkas LG, Mulliken JB. Photogrammetric comparison of two methods for synchronous repair of bilateral cleft lip and nasal deformity. Plast Reconstr Surg 1998;102:1339-1349.

14. Pena SD, Di Pietro G, Fuchshuber-Moraes $M$, Genro JP, Hutz MH, Kehdy FdSG, et al. The genomic ancestry of individuals from different geographical regions of Brazil is more uniform than expected. PloS one 2011:6:e17063

15. Ferrario VF, Sforza C, Serrao G, Ciusa V, Dellavia C. Growth and aging of facial soft tissues: A computerized three-dimensional mesh diagram analysis. Clin Anatomy 2003;16:420-33.

16. Ozdemir F, Uzun A. Anthropometric analysis of the nose in young Turkish men and women. J Craniomaxillofac Surg 2015;43:1244-1247.

17. Zacharopoulos GV, Manios A, Kau CH, Velagrakis G, Tzanakakis GN, Bree E. Anthropometric analysis of the face. J Craniofac Surg 2016;27:e71-e75.

18. da Silva AMBR, Magri LV, Andrade LM, da Silva MAMR. Three-dimensional analysis of facial morphology in Brazilian population with Caucasian, Asian, and Black ethnicity. J Oral Res Rev 2017:9:1-7.

19. Tanikawa C, Zere E, Takada K. Sexual dimorphism in the facial morphology of adult humans: a three-dimensional analysis. Homo 2016;67:23-49.

20. Leong SC, Eccles R. A systematic review of the nasal index and the significance of the shape and size of the nose in rhinology. Clin Otolaryngol 2009;34:191-198.

21. Mehta N, Srivastava RK. The Indian nose: An anthropometric analysis. Forensic Sci Inter 2017;70:1472-1482.

22. Reis J. Brasil: 500 anos de povoamento. Rio de Janeiro, IBGE, 2000

23. Ruiz-Linares $A$, Adhikari $K$, Acuña-Alonzo V, Quinto-Sanchez $M$, Jaramillo $C$, Arias W, et al. Admixture in Latin America: geographic structure, phenotypic diversity and self-perception of ancestry based on 7,342 individuals. PLoS Genet 2014;10:e1004572.

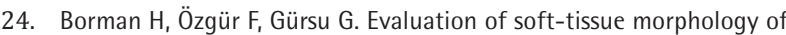
the face in 1,050 young adults. Ann Plast Surg 1999;42:280-288.

25. Franklin D, Freedman L, Milne N. Sexual dimorphism and discriminant function sexing in indigenous South African crania. Homo 2005:55:213-228.

26. Burton AM, Bruce V, Dench N. What's the difference between men and women? Evidence from facial measurement. Perception 1993;22:153176.

27. Kononenko I. Machine learning for medical diagnosis: history, state of the art and perspective. Artif Intell Med 2001;23:89-109.

28. Crown WH. Potential application of machine learning in health outcomes research and some statistical cautions. Value Health 2015:18:137-140. 